\title{
Institutional dimension for sustainable development: the relationship of organic and conventional cotton farming with government
}

\author{
Dimensão institucional para o desenvolvimento sustentável: as relações da \\ cotonicultura orgânica e da convencional com o governo
}

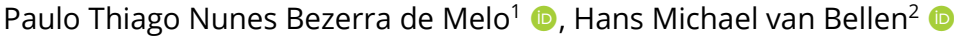 \\ ${ }^{1}$ Universidade Federal Rural de Pernambuco (UFRPE), Serra Talhada (PE), Brasil. E-mail: pthiagoadm@hotmail.com \\ ${ }^{2}$ Universidade Federal de Santa Catarina (UFSC), Florianópolis, (SC), Brasil. E-mail: hansmichael.vanbellen@gmail.com
}

\begin{abstract}
How to cite: Melo, P. T. N. B., \& van Bellen, H. M. (2022). Institutional dimension for sustainable development: the relationship of organic and conventional cotton farming with government. Revista de Economia e Sociologia Rural,
\end{abstract} 60(1), e224662. https://doi.org/10.1590/1806-9479.2021.224662

\begin{abstract}
This study aimed to examine the institutional dimension of conventional and organic cotton farming; specifically, the relationships between farms and government organizations. In both, conventional and organic production systems, the farmers are located in varying institutional environments. These environments include a social capital formed by relationships of trust and cognitive affinities. This study focused on the social capital and guidelines for sustainable development. Multiple study cases were used for explanatory purposes. Such cases refer to a conventional cotton farming business and a civil society organization dedicated to organic cotton farming, both located in the state of Piauí. A comparative analysis perspective was adopted based on the elements of content analysis. The results showed that the conventional cotton farming business comprises relationships with governmental organizations that are predominantly oriented towards economic efficiency purposes, while the family-based organic cotton farming association comprises relationships oriented by economic, social, and environmental objectives. The present study extends the discussion on these topics by analyzing the institutional dimension oriented towards the sustainable development premises.
\end{abstract}

Keywords: sustainable development, social capital, social networks.

Resumo: Estudo buscou analisar a dimensão institucional da cotonicultura convencional e orgânica; especificamente, as relações entre os estabelecimentos rurais e organizações governamentais. Em ambos os sistemas produtivos, convencional e orgânico, os produtores estão inseridos em diferentes ambientes institucionais. Esses ambientes incluem um capital social formado por relações de confiança e afinidades cognitivas. Este estudo tem como foco o capital social e as orientações para o desenvolvimento sustentável. Um estudo de casos múltiplos foi adotado com propósito explanatório. Esses casos referem-se a uma empresa de cotonicultura convencional e uma organização da sociedade civil dedicada à cotonicultura orgânica, ambas localizadas no estado do Piauí. Adotou-se uma perspectiva de análise comparativa com base nos elementos da análise de conteúdo. Os resultados mostraram que o negócio da cotonicultura convencional compreende relações com órgãos governamentais predominantemente orientados para propósitos de eficiência econômica, enquanto a associação de cotonicultura orgânica de base familiar compreende relações orientadas por objetivos econômicos, sociais e ambientais. O presente estudo amplia a discussão sobre esses temas, analisando a dimensão institucional orientada para o desenvolvimento sustentável.

Palavras-chave: desenvolvimento sustentável, capital social, redes sociais.

\section{Introduction}

The present study compared institutional dimensions in conventional and organic cotton farming. The relationships between farms and government organizations were considered. 
From this perspective, governmental agencies in both conventional and organic production systems are considered by cotton farmers as stakeholders who are part of the institutional environment. This study focused on the institutional environments in which cotton farmers interact with governmental organizations. This interaction constitutes a social capital that can be associated with the concept of sustainable development.

Well-developed structural social capital is not sufficient for enabling sustainable development when the contents and values do not reflect the established ideal. The question that guided the present study was: what are the development purposes that guide the relationships between organic and conventional cotton farming with governmental organizations? In this sense, it was aimed that organic agriculture relationships with governmental organizations are oriented towards economic, social, and environmental purposes, while the government relationships with conventional agriculture are oriented mainly towards economic purposes. Thus, this article proposes to show the importance of the idea of sustainable development in the content of trust relationships and the presence of cognitive affinity. Sustainable development depends upon relationships and meanings that guide the actions of individuals. These individual actions are important in changing or forming habits. Thus, habits support the institutions built throughout history (Hodgson, 1998) and that is based on the context that permeates the relationship between individuals.

The institutional perspective was adopted, which entails the relations of governmental organizations and their consequences in development processes (March \& Olsen, 2008). According to Lopolito et al. (2011), institutions that utilize concrete social practices evolve after each action. This factor becomes social capital for new development projects. This institutional dimension of development is indicated by the social capital established between organizations, which is understood as a set of relational assets that can affect an organization's productive capacity (Lopolito et al., 2011). These relational assets can be found in the diversity of contacts, relationships of trust, and cognitive affinities present in the relationship networks. These assets correspond to the structural, relational, and cognitive dimensions of social capital (Nahapiet \& Ghoshal, 1998). In this sense, farms contain social capital because they share priorities and build trust with groups of other organizations.

Conventional cotton has one of the highest use of pesticides among cultivated crops. Approximately $24 \mathrm{~L}$ per cultivated hectare are utilized. This requires strategies to prevent damage to public health (Pignati et al., 2014). Organic agriculture is perceived as an alternative cultivating strategy, which is better capable of promoting the welfare of economic, sociocultural, and ecological assets. This outcome would be oriented towards sustainable development (Altieri \& Nicholls, 2012). However, this benefit of organic agriculture depends on the support of institutional relationships. These relationships promote cognitive affinity and trust that are oriented to promote sustainable development. Two cases of cotton farming were analyzed in this study to compare the relational purposes between governmental organizations within different institutional frameworks.

The present study contributes to the understanding of organizations by demonstrating the importance of cognitive affinity content and trust in relationships with governmental organizations. These two principles are important in terms of sustainable development to qualify the established social capital. In this sense, extends the understanding of development dynamics through empirical and comparative analysis. The importance of relational optics in the formation of institutional capacities is demonstrated while emphasizing the content of relationships. Although the number of studies on the institutional dimension has increased in recent decades, only the structural and formal dimensions are often addressed (e.g. analyzing patterns of connections, roles of actors, and governance devices). Currently, there is a lack of studies, especially empirical, discussing the cognitive and relational aspects of the institutional dimension. These aspects encompass the contents of the relationships. This article presents the theoretical framework for the sustainable development of cotton farming along with the institutional dimension. The multiple case study methodology was used in the research and discussions of the results and conclusions on conventional and organic cotton farming are presented. 


\section{Sustainable development in cotton farming}

Historically, Brazilian agriculture has developed dynamically. Recently, it has assumed different forms in search of systems that have more positive outcomes. The orientation towards the international market of business agriculture stimulated Brazil to specialize in the export of agricultural products globally (Ribeiro \& Markwald, 2009; Jorge, 2009). On the other hand, the integration of territorial arrangements, which emphasize the implementation of organic production systems and agroecology, has enhanced autonomy for family farmers (Jalfim et al., 2013).

While the rationale of international markets has legitimized business agriculture, the processes of recognition and commercialization of organic agriculture have taken place with the support of participatory certifications. This mechanism allows the social control of farmers by requiring compliance with the norms of agroecological production. These were defined by a collective framework (Serva \& Andion, 2004) which provided credibility in a decentralized process and ensures the quality of products (Rover, 2011). In addition to the Brazilian public policies that promote business agriculture, governments have also recognized the importance of local markets for organic family-based agriculture. This allows for the existence of hundreds of public fairs for these products throughout Brazil (Flores, 2013).

Family farmers have received training and technical assistance, including seeds adapted to agroecological cultivation (available to community seed banks) from government organizations (Jalfim et al., 2013). An example of this type of support is the Dom Helder Camara Project (PDHC), which was created in 2001 within the scope of the Secretariat of Territorial Development of the Ministry of Agrarian Development and is supported by the International Fund for Agricultural Development (IFAD). PDHC had emerged to meet the demand for sustainable rural development of family farming in the northeastern semi-arid region while adopting the paradigm of agroecology. Currently, PDHC is managed by the Secretariat of Family Agriculture and Cooperatives of the Ministry of Agriculture, Livestock and Food Supply (MAPA).

According to Altieri \& Nicholls (2012), organic agriculture has social benefits for the health of individuals and the environment, thus contributing to sustainable development. In other words, these authors emphasized that although some agro-industrial systems adopted sustainability programs recently, agriculture in its modern and industrial form contributes to environmental problems, including climate change. As a consequence, agricultural systems promote and are promoted by institutional frameworks that foster different types of development, whether sustainable or spurious. Based on Haddad's (1999) work, the concept of sustainable development was discussed by Santos (2011). Santos (2011) considered the predominance of a rationale of maintaining the environment which is associated with increased productivity, jobs, and population income. On the other hand, spurious development occurs when there is a predominance of an approach prioritizing economic growth but not mitigating dependence on government incentives, degradation of the environment, excessive exploitation of labor, and the use of illegal practices (informal employment of workers, tax crimes, and illegal deforestation) (Santos, 2011; Haddad, 1999).

Spangenberg (2002) emphasized that sustainable development has economic, social, and environmental dimensions, and indicated that sustainable development has the goals of improving economic competitiveness, protecting social cohesion, and restricting the use of natural resources in production processes. Understanding the economic dimension involves the comprehension of government participation in total rents, the risks of using primary resources as the basis of international trade, and investments in advanced technologies. The social dimension is understood by the belief in the employees' vulnerability in the labor market and the system of wealth redistribution. The environmental dimension, in turn, is understood by the perception of the emphasis on the protection of biodiversity and the intensity of the economy in natural resources (Spangenberg, 2002). Assis (2006) pointed out that organic agriculture can promote sets of economic, sociocultural, and ecological assets, which provide the basis for sustainable development processes. 
Table 1 shows a synthesis of economic, sociocultural, or ecological assets, comparing the conventional and organic cotton production methods.

Table 1: Economic, sociocultural, or ecological assets in cotton farming.

\begin{tabular}{|c|c|c|}
\hline & Conventional & Organic \\
\hline \multirow{5}{*}{$\begin{array}{l}\text { ECONOMIC ASSETS } \\
\text { (Faria \& Pereira, 2012; } \\
\text { Associação Brasileira dos } \\
\text { Produtores de Algodão, } \\
\text { 2013; Jalfim et al., 2013; } \\
\text { Beltrão et al., 2010; Ferreira- } \\
\text { Filho et al., 2009) }\end{array}$} & - Concentrated economy; & - Solidarity economy; \\
\hline & $\begin{array}{l}\text { - Average productivity of } \\
3,500 \mathrm{~kg} / \mathrm{ha} ;\end{array}$ & $\begin{array}{l}\text { - Average productivity of } 1,000 \text { kg / } \\
\text { ha; }\end{array}$ \\
\hline & $\begin{array}{l}\text { - Remuneration per kilo is } \\
\text { half of that obtained with } \\
\text { organic; }\end{array}$ & $\begin{array}{l}\text { - Remuneration per kilo is double of } \\
\text { that obtained in conventional; }\end{array}$ \\
\hline & $\begin{array}{l}\text { - } 37 \% \text { of total costs are with } \\
\text { pesticides; }\end{array}$ & - Eliminates pesticide costs; \\
\hline & • Scale gains. & - Differentiation gains. \\
\hline SOCIOCULTURAL ASSETS & $\begin{array}{l}\text { - Weakened autonomy of } \\
\text { rural populations; }\end{array}$ & $\begin{array}{l}\text { - Strengthened social autonomy of } \\
\text { rural populations; }\end{array}$ \\
\hline \multirow{2}{*}{$\begin{array}{l}\text { (Andrada \& Sato, 2014; } \\
\text { Serva \& Andion, 2004; Faria } \\
\text { \& Pereira, 2012; Alves et al., } \\
\text { 2008; Assis \& Romeiro, } \\
\text { 2002) }\end{array}$} & $\begin{array}{l}\text { - Business labor relations in } \\
\text { agro-industrial systems; }\end{array}$ & $\begin{array}{l}\text { - Associative relationships of trust } \\
\text { and cooperation between farmers; }\end{array}$ \\
\hline & $\begin{array}{l}\text { - Appreciation of scientific- } \\
\text { technological knowledge of } \\
\text { modern agronomy. }\end{array}$ & $\begin{array}{l}\text { - Appreciation of peasant cultural } \\
\text { knowledge and agroecology. }\end{array}$ \\
\hline ECOLOGICAL ASSETS & $\begin{array}{l}\text { - Cerrado biome and its } \\
\text { regular rainfall; }\end{array}$ & $\begin{array}{l}\text { - Caatinga biome and its periods of } \\
\text { drought; }\end{array}$ \\
\hline \multirow{2}{*}{$\begin{array}{l}\text { (Cruz \& Maia, 2008; } \\
\text { Companhia Nacional de } \\
\text { Abastecimento, 2016; } \\
\text { Jalfim et al., 2013; Faria \& } \\
\text { Pereira, 2012) }\end{array}$} & $\begin{array}{l}\text { - Reduces local biodiversity } \\
\text { by more than } 320,000 \\
\text { hectares; }\end{array}$ & $\begin{array}{l}\text { - Promotes local biodiversity on } \\
\text { approximately 32,000 hectares; }\end{array}$ \\
\hline & $\begin{array}{l}\text { - Does not promote } \\
\text { environmental education for } \\
\text { sustainability. }\end{array}$ & $\begin{array}{l}\text { - Promotes environmental education } \\
\text { and awareness for sustainability. }\end{array}$ \\
\hline
\end{tabular}

Source: Prepared by the authors.

Faria \& Pereira (2012) demonstrated that organic cotton farming economic assets with great distributive capacity increase when they are offered fair trade circuits. Also, these assets increase the sociocultural benefit resulting from associative relationships of trust and cooperation between farmers. Finally, it is possible to observe the ecological benefit of environmental education for farmers and rural populations.

Conventional and organic cotton farming systems promote different sociocultural assets. In organic cotton farming, rural populations have greater social autonomy, which is expressed by their capacity of defining their standards, which are officially recognized in the legal apparatus (Serva \& Andion, 2004). This results from an engagement in participatory certification processes and the formation of solidarity economies based on self-management (Andrada \& Sato, 2014). In contrast, rural populations in conventional cotton farming are subjected to the already structured conditions of their agro-industrial system. These conditions are manifested in the business labor relations that farmers establish with the agroindustrial companies of conventional cotton farming in northeast Cerrado. In contrast, organic cotton farming, within Caatinga, occurs through associative relationships of trust and cooperation between farmers (Faria \& Pereira, 2012).

Spangenberg (2002) contributed to the discussion by adding the institutional dimension to the economic, social, and environmental dimensions. This formulation, which considers four dimensions of development, is referred to as the Sustainability Prism. The concern with the institutional dimension of the development process emerged in Agenda 21, which is a document adopted by members of the United Nations whose purpose is to promote sustainability actions at the global, national, and local levels (Spangenberg, 2002; United 
Nations, 1992). Although Agenda 21 already considered the institutional dimension in 1992, it was only at Rio +20 in 2012 that it appeared as a principal issue in the discussion agenda (Melo, 2013).

\section{The institutional dimension of sustainable development}

Institutions have been the subject of study in different areas and analysis methodologies. Organizational studies on institutions have analyzed their internal dynamics and discussed the structures of organizations (Meyer \& Rowan, 1977; DiMaggio \& Powell, 1983). Economic studies were conducted to examine the effects of institutions and their decision trajectories on actions and economic performance (North, 1990; Veblen, 1987). Hodgson (1998), an economic thinker, clarified the central proposition in the original institutionalist: the nature of individuals is characterized by actions which are guided by habits and are comprised by a set of possible behaviors with different explanations for behavior origin and evolution. The discussion on institutions adopting a political approach, in turn, emphasizes the interdependence between social and political-governmental entities in the dynamics of development (March \& Olsen, 2008). Some researchers interested in the topic of sustainable development have dedicated themselves to this discussion, applying the concept of institutions differently from each other (Table 2).

Table 2: Applications of the institution conception

\begin{tabular}{ll}
\multicolumn{1}{c}{ Authors } & \multicolumn{1}{c}{ Applications on the topic of sustainable development } \\
$\begin{array}{l}\text { Spangenberg } \\
\text { (2002) }\end{array}$ & $\begin{array}{l}\text { Social entities appear as actors in political processes and systems of rules, which } \\
\text { structure political behavior and facilitate social orientations. }\end{array}$ \\
Pfahl (2005) & $\begin{array}{l}\text { Institutions consist of organizations, governments, systems of rules, mechanisms, } \\
\text { social norms, traditions, and guidelines. }\end{array}$ \\
$\begin{array}{l}\text { Vogelpohl \& } \\
\begin{array}{l}\text { Aggestam } \\
\text { (2012) }\end{array}\end{array} \quad \begin{array}{l}\text { Institutions are not only specific formal public and government service } \\
\text { important to society. Institutions also are patterns that have emerged after long }\end{array}$ \\
$\begin{array}{l}\text { Lopolito et al. } \\
\text { periods and resist changing. }\end{array}$ \\
$\begin{array}{l}\text { Joint action is carried out concretely, which results in a plan and can be used as a } \\
\text { practice of social capitalization in new development projects. Joint action is a }\end{array}$ \\
\hline
\end{tabular}

Source: Prepared by the author.

In the present study, the institutional dimension was analyzed by collective actions, following the recommendation of Lopolito et al. (2011). When discussing collective action programs in rural Italy, these authors relate the institutional dimension of development to the notion of social capital, which serves the purpose of strengthening citizen participation in sustainable development according to the concept originally proposed by Spangenberg (2002).

From a sociological perspective, Coleman (1988) defined social capital as the function of social structures that facilitate the progress of actors within them. In the political sciences, Putnam (2002) indicated that social capital facilitates coordinated actions to increase the efficiency of society. Social capital is defined as a set of characteristics of the social organization that includes trust, norms, and systems. In the field of business administration, Nahapiet \& Ghoshal (1998) understood social capital as a set of resources of an individual or social entity that are present and are accessed through social networks. Based on these concepts, Lopolito et al. (2011) understood social capital as the set of relational assets that can affect an organization's productive capacity, including the diversity of network contacts, trust relations, and cognitive affinity in sharing views on how to identify and solve problems.

The actors involved in agricultural systems are immersed in interorganizational relationships, which can restrict or facilitate certain purposes, consequently, manifesting 
different qualities of social capital. For example, Souza \& Caldas (2018) stated that alternative food chain organizations formed by buyers have significant potential in building social capital. Espinosa et al. (2018) pointed out that the most sustainable organizations involve their associated farmers in participatory work schemes, include their members and other actors, and strengthen their social capital. Sampaio et al. (2018) stated that the increase in participation and effectiveness of joint actions in a Local Productive Arrangement is due to the social capital formed in the trust, engagement, and involvement of agents. Silva et al. (2016), in turn, observed the presence of weak or limited social capital in a family farming cooperative. The presence of distrust among its participants was evident along with the formality of their relationships when using marketing facilities and purchasing inputs.

The system developed by Lopolito et al. (2011) to assess the institutional dimension through social capital was based on the contribution of Nahapiet \& Ghoshal (1998). The concept is organized in three different ways: structural, relational, and cognitive dimensions. The analysis of the structural dimension emphasizes the connection patterns of the actors in the relationship networks and the gains in access to information according to their positions (Burt, 2007). Although structural analysis is important, the present study reinforces the proposition that the quality of social capital depends on its relational and cognitive dimensions. The quality of social capital is indicated by the ideological content exchanged in the relationships of trust and by the main shared values reflected in the cognitive affinity between the actors (Chambers \& Kopstein, 2001). However, the structural dimension is not ignored, as this study proposes that its importance lies in attenuating or accentuating the quality of social capital according to the structural configuration of relations. Structural configurations with a lower density of loops attenuate the contents and meanings by allowing a greater diversity of values, while configurations with a higher density of loops accentuate a given set of contents and meanings by reinforcing homogeneous values.

Relational social capital refers to the fundamental reciprocity that guides exchanges, and a high level of trust may allow the transfer of confidential information (Andrews, 2010). This dimension is related to internal trust and cooperation relations between the actors of a social group (Lopolito et al., 2011). The relational dimension describes social relationships that can influence behavioral aspects and fulfill social expectations, which can be observed in norms and consequent social sanctions and relationships of trust (Hartmann \& Serafim, 2014). Cognitive social capital refers to the degree to which subjective interpretations of organizational values and objectives are shared, forming the context whose knowledge exchange and collective actions take place (Andrews, 2010). This dimension is related to the level of cognitive affinity, which reflects the sharing of views (Lopolito et al., 2011). The cognitive dimension refers to the interpretations and meanings represented in language, codes, and narratives, which can be observed in the organization's history, shared views, and common values (Hartmann \& Serafim, 2014). The presented theoretical framework was investigated. A comparison of the relationships between actors in conventional and organic cotton farming and governmental organizations is performed based on the methodology described below.

\section{Methodology}

This study aimed to focus on the interactions of two organizations (organic and conventional cotton farming) with governmental organizations. The strategy of multiple case studies with explanatory purpose was adopted per the recommendations of Yin (2005). Such cases refer to the interactions established between a conventional cotton farming business called Fazenda Progresso (located in Piauí within the "MAPITOBA" region, an acronym for the federative units where the new agricultural frontier of Brazil has advanced [Maranhão, Piauí, Tocantins, and Bahia]) and a civil society organization dedicated to organic cotton farming 
(recognized as a participatory organic conformity assessment body - OPAC ${ }^{1}$, called APASPI [Association of Agroecological Farmers of the Piauiense Semi-arid]).

Primary and secondary data were obtained through three different sources of evidence (Yin, 2005): documents, direct observations, and interviews. The research was conducted between September and October 2014. Primary data were collected in a field environment with visits to organizations, using direct non-systematic, non-participatory observations that were recorded in field notes. Three visits were made to APASPI to observe the settlement environment where both the organization is located and the cotton processing occurs. A visit was to the conventional cultivation company was carried out to observe the company's facilities, the processing and preparation of the cotton for transportation, the storage of seeds, and the cultivation area. Interviews were conducted to record the perceptions of managers and representatives of the sector regarding the relationships of trust, the sharing of views on the problems confronted, and the strategies adopted to solve the problems. In the case of organic cotton farming, a manager, a member of the ethics committee, a member of the evaluation committee, and the president of APASPI were interviewed. In conventional cotton farming, a commercial manager, the agronomist responsible for the crops, and the executive director of the Piauiense Association of Cotton Farmers were interviewed. Moreover, documents, such as bylaws, news published on official pages, minutes of meetings at MAPA, annual association report, and interviews in journalistic magazines were assessed to complement the analysis by searching for convergences or divergences that needed to be better understood.

The analysis perspective adopted in this study is similar to the "synthesis of crossed cases" as described by Yin (2005, p. 163-167). In this perspective, content analysis, according to the analysis perspective reported by Bardin (2006), is used to discover the "nuclei of meaning" that constitute the statements of each interviewee and the texts of the documents. The following categories and subcategories of analysis are utilized as thematic groups (Table 3).

Table 3: Categories of analysis

\begin{tabular}{|c|c|c|}
\hline Categories & Subcategories & Description \\
\hline \multirow[t]{2}{*}{$\begin{array}{l}\text { Forms of social capital } \\
\text { (Lopolito et al., 2011) }\end{array}$} & Relational form & $\begin{array}{l}\text { Establishment of relationships of trust and } \\
\text { cooperation }\end{array}$ \\
\hline & Cognitive form & $\begin{array}{l}\text { Affinity in opinions regarding the problems } \\
\text { confronted and the strategies to solve them }\end{array}$ \\
\hline \multirow{3}{*}{$\begin{array}{l}\text { Dimensions of } \\
\text { sustainability } \\
\text { (Spangenberg, 2002) }\end{array}$} & $\begin{array}{l}\text { Economic } \\
\text { dimension }\end{array}$ & Improving the competitiveness of the economy \\
\hline & Social dimension & Protection of social cohesion \\
\hline & $\begin{array}{l}\text { Environmental } \\
\text { dimension }\end{array}$ & $\begin{array}{l}\text { Restriction of natural resources in production } \\
\text { processes }\end{array}$ \\
\hline
\end{tabular}

Source: Prepared by the author

The material was analyzed and the themes that appeared in the data were identified and coded according to predefined topics. Using a spreadsheet, the themes that emerged were listed and related to a code identifying the data source related to that theme. The themes were grouped by similarities between them, forming broader thematic groups according to the subcategories listed in Table 3. Table 4 describes the cases studied.

1 OPAC is an entity formed by family farmers that certifies organic quality according to MAPA regulations and technical standards (Brasil, 2008). 
Table 4: Studied cases.

\begin{tabular}{|c|c|}
\hline Conventional cotton & Organic cotton \\
\hline $\begin{array}{l}\text { The company was founded and is currently } \\
\text { managed by a family, who emigrated from } \\
\text { Holland to Brazil after the Second World War. } \\
\text { Subsequently, the family performed rural work } \\
\text { in the interior of São Paulo and Rio Grande do } \\
\text { Sul. The family patriarch founded the company } \\
\text { after having conducted agricultural business } \\
\text { during the latter 1970s in partnership with his } \\
\text { brothers in Minas Gerais, Mato Grosso do Sul } \\
\text { and Mato Grosso. The founding entrepreneur } \\
\text { started producing cotton in Mato Grosso do Sul } \\
\text { in } 1993 \text {, in an area located in Dourados, but the } \\
\text { inability to mitigate the effects of the rainy } \\
\text { periods on production caused a search for new } \\
\text { areas for the activity. In } 2000 \text {, he and his son, the } \\
\text { current director of the company, started looking } \\
\text { for new areas for production. This resulted in } \\
\text { the acquisition of an area in the cerrado of Piauí, } \\
\text { west of the Serras das Confusões and Capivara. } \\
\text { The company was established in } 2001 \text {, in a } \\
\text { region known as the country's new agricultural } \\
\text { frontier. In addition to cotton farming, the } \\
\text { company produces corn and soybean along with } \\
\text { the production and sale of transgenic soybean } \\
\text { seeds. The company's operations are } \\
\text { technology-intensive for large-scale production. }\end{array}$ & $\begin{array}{l}\text { The organization is composed of remnants and } \\
\text { descendants of the Zabelê people, who } \\
\text { previously inhabited areas interior to the Serra } \\
\text { da Capivara National Park. The Zabelê people } \\
\text { lived integrated with the environment and had } \\
\text { economic support with the extraction of latex } \\
\text { from maniçoba. In that same region, } \\
\text { archeologist Niède Guidon found a series of cave } \\
\text { paintings and other traces that indicated the } \\
\text { presence of one of the most remote peoples in } \\
\text { the Americas. Archaeological discoveries and the } \\
\text { historical importance of the site resulted in the } \\
\text { creation of the Serra da Capivara National Park } \\
\text { in } 1979 \text { which resulted in the evacuation of the } \\
\text { people who inhabited park areas. After years, } \\
\text { the remnants and descendants of the Zabelê } \\
\text { people were allocated the Fazenda Lagoa } \\
\text { settlement by INCRA in } 1997 \text {. Subsequently, the } \\
\text { area became known as Povoado Novo Zabelê } \\
\text { and houses approximately } 250 \text { families. This } \\
\text { settlement is located near the city of São } \\
\text { Raimundo Nonato, east of the mountain ranges } \\
\text { of the confusions and the capybara. In } 2005 \text {, the } \\
\text { settlement community began to receive support } \\
\text { from the Dom Helder Camara Project for } \\
\text { cultivation based on the principles of } \\
\text { agroecology of various products in consortium } \\
\text { with cotton and for the creation of APASPI in } \\
2012 \text {. }\end{array}$ \\
\hline
\end{tabular}

Source: Prepared by the author.

The categorization phase prioritized the theoretical framework of this study while preserving the contribution of the interpretation and the pragmatic meaning of the data. The interpretation and meaning of the data were described without the intention of fragmenting them into mutually exclusive categories of analysis and consequently losing the authenticity of their meanings (Mattos, 2005). The present work sought to identify more comprehensively social capital in the forms of trust and cognitive affinities in the relationships between the organizations studied and governmental organizations. Moreover, it was aimed to evaluate the quality of this social capital considering its adherence to economic, social, and environmental purposes, which represent the dimensions of development as a category of analysis. Throughout the analysis process, it was aimed to identify the presence or absence of the categories and themes and associate them with organic and/or conventional cotton. This analysis allowed inferences and interpretations to be created completing the analysis.

After the analysis, discussions of the obtained results are presented, comparing the relationships of the conventional and organic cotton organizations with the governmental organizations. The following sections present these discussions based on the economic, social, and environmental, and sustainable development dimensions.

\section{Economic dimension}

The economic gains from relationships with governmental organizations in conventional cotton farming result from logistical infrastructure issues. The studied company (conventional cotton) is part of APIPA (Piauiense Association of Cotton Farmers), which is part of the Sectorial Chamber of the Cotton and Derivatives Productive Chain within the scope of MAPA. This 
chamber establishes relationships with several organizations within this production chain and makes proposals along with monitoring its activities. At the meetings of this chamber, representatives of APIPA present analyses of the actions of the National Department of Transport Infrastructure (DNIT) of the Ministry of Transport that impact logistics costs. For example, an analysis presented at a chamber meeting indicated:

[...] the measurement instruments used by DNIT weigh only axles, while road scales for commercial establishments and farmers allow only obtaining the total weight of the vehicles, which shows a gap between the two systems. (Brasil, 2012).

DNIT is responsible for the maintenance, construction, and inspection of roads, which influences the logistic operations of cotton farming. Other studies demonstrate the importance of logistics infrastructure for the performance of the agricultural sector (Aguiar et al., 2013; Ferro \& Castro, 2013). The Brazilian Association of Cotton Producers (ABRAPA) states that improvements in logistics infrastructure are a critical factor in the cotton production chain, as presented in the following excerpt:

Infrastructure investment has been one of the targets of one of the main programs of the federal government in the last administrations: The Growth Acceleration Program (Programa de Aceleração do Crescimento - PAC). Some of its work stands out for their importance for agriculture practiced in the cerrado regions of Brazil and, consequently, for cotton, such as the expansion and paving of the BR-163 and the North-South Railway. (Associação Brasileira dos Produtores de Algodão, 2013, p. 154).

Improvements in the production transport infrastructure have positive effects that benefit the entire sector, including organic cotton. The performance of the Sectorial Chamber is aligned with the considerations regarding the institutionalization of MAPA as an organization that supports business agriculture in the Brazilian agricultural sector (Sabourin, 2007). The relationships between representatives of conventional cotton farming and MAPA need trust in the investment's priorities to improve the sector's competitiveness.

In conventional cotton farming, cognitive affinity in identifying field problems and implementing solutions with government organizations to avoid production losses is less likely to occur. These relationships require the fulfillment of bureaucratic processes that result in difficulty in satisfying the urgent needs of farmers. The following excerpt from the interview with the agronomist of the company studied illustrates this issue:

Farmers are usually well ahead than, for example, the official bodies: CONAB and the Ministry because that is part of their reality. For example, farmers need to resolve problems quickly. [...]. Because when you go to official bodies, like it or not, there is a lot of bureaucratic procedures and, sometimes, it takes time, right? This is what we see. (Engineer responsible for crops).

According to the executive director of APIPA, the agriculture sector has shown the best results in the Brazilian economy ${ }^{2}$ because of the engagement of farmers, despite the lack of support from the government sector. In his view, government actions for agriculture are based on particular political interests, rather than interests in economic development, as shown in the following excerpt from the interview:

The government ministries do not recognize ${ }^{3} . .$. what the agriculture sector is doing. And if we are recognized by one of them... we face some difficulty, a part of the government does not recognize agriculture, does not consider agriculture, and I am not only talking about agribusiness. I am also talking about family farming and the in-between. This is politically

\footnotetext{
${ }^{2}$ Agricultural products had a positive balance of US $\$ 61$ billion in the trade balance in 2017, 10 times greater than in 1993 (Food and Agriculture Organization of the United Nations, 2020).

${ }^{3}$ At that time, the federal government had Dilma Rousseff as president and Neri Geller as minister at MAPA.
} 
motivated and not economically motivated. There is a political interest and not an economic recognition. (Executive Director of APIPA).

The search for greater productivity in agricultural companies has been stimulated by the appreciation of commodities in the international market and by increases in exports (Ribeiro \& Markwald, 2009; Jorge, 2009). On the other hand, such specialization in Brazil is not the result of government support for the economic development of the sector, as is the case in the United States cotton industry. This support can result in economic consequences in the international market that negatively impact other producing countries (Ferreira-Filho et al., 2009). Regarding the case of organic cotton farming, APASPI was formed in a rural settlement whose demands were analyzed by INCRA (National Institute for Colonization and Agrarian Reform). The community's welfare was intricately linked to the economic gains obtained by making unused land productive. However, the demands of the farmers' association were not met by this governmental organization, hindering the building of trust in the relationship due to the duration of administrative processes.

[...] it takes a long time to get things done with INCRA. We still struggle a lot with INCRA because they cannot do some things that they must do here in the settlement [...]. Although INCRA must provide technical assistance within the settlements, they never did that. (President of the association)

The absence of INCRA was compensated by the relationship of trust built between the organic cotton association and the PDHC. This relationship promoted the construction and development of skills for farmers to obtain higher incomes. An association manager said: "I personally trust a lot because of the large number of benefits generated for us through a greater knowledge of things, courses, and visits, these things." EMBRAPA is also a government organization that has a trust relationship with the studied association. Direct observations allowed to monitor the support provided by EMBRAPA, such as providing seeds suitable for organic cultivation and assisting in the ginning and pressing of cotton.

The studied association is OPAC accredited by MAPA, which certifies the compliance of organic products for commercialization through participatory systems (Jalfim et al., 2013). The documents accessed showed that the accreditation process established a relationship of trust indicated by meetings between managers of the organizations and inspection visits to maintain the association as an OPAC. However, the relationship with MAPA depends upon a coordination unit within a department of a secretariat. In organic cotton farming, the involvement of government organizations in the marketing solution relies on the accreditation as an OPAC and the legitimation of participatory certification. Recognizing the quality of organic products allows them to be marketed and increase their competitiveness in the market, thus expanding the economic dimension of development. Through the affinity with MAPA in the solution for marketing its products with the participatory certification of organic products, the studied association achieved an institutional development that allowed an increase in the families' income.

Organic agriculture is seen as a productive system capable of promoting local cotton production and improving household income, resulting in benefits in the economic development of the communities that dedicate themselves to this practice. The studied association sends its production to the international fair-trade market. Farmers integrated into fair trade circuits achieve greater income than they would through common trade channels (Faria \& Pereira, 2012).

Participatory certification is an institutional construct that promotes the economic dimension of regional development. It stimulates organic production in Brazilian territory, allowing family farmers to sell their products through direct marketing channels such as local fairs (Flores, 2013). On the other hand, participatory certification is not recognized in international trade markets, as is the fair trade arrangement that the studied association is part of, limiting its potential to promote the economic dimension of development. These 
foreign trade markets require that the products be certified by an audit process, which is a challenge for family farmers dealing with purchasing companies in fair trade circuits (Jalfim et al., 2013). In 2019, Brazil's first common certification system for organic products in international trade was established through an equivalence agreement with Chile. For Brazilian organic cotton farming, advances such as these can promote its competitiveness, especially if they occur in the scope of the agreement between Mercosur and the European Union, which is the principal destination of its products.

\section{Social dimension}

In conventional cotton farming, the social dimension of sustainable development is expressed in the relationships with ANVISA (Brazilian Health Regulatory Agency), which regulates the use of agrochemicals. ANVISA is an organization whose actions are oriented towards public health issues. Its jurisdiction extends to rural areas and it regulates chemicals that are harmful to human beings. Thus, the social dimension involves the maintenance of long-term well-being at a level that allows current and future generations to have the opportunity to enjoy a good quality of life (Bijl, 2011).

The establishment of trust relationships between cotton farmers and ANVISA is difficult due to the difference in the areas of operation and the rate of progress for administrative processes in public organizations. This rate of process results in difficulty in addressing the urgency of farmers to make use of some products developed by chemical industries to combat pests, according to the executive director of APIPA:

[...] we are having a lot of difficulty with ANVISA with regard to the release of new products. ANVISA is not a body linked to agriculture. ANVISA is an agency linked to the Ministry of health, falling outside of the scope of agriculture. However, the release of new products goes through ANVISA. And then, we have problems. [...]. It is difficult to address this issue and for the processes to move forward. (Executive Director of APIPA)

Given the intensive use of agrochemicals in the crops of the conventional cotton grower, it is necessary to better involve ANVISA to establish trust relationships based on cooperation with farmers. Differences in interests between farmers and governmental organizations do not allow the establishment of cognitive affinity in identifying problems and implementing solutions. Handling with helicoverpa caterpillar infestation in cotton production was an example of these differences:

Sometimes, farmers want that their problems to be solved immediately, and these other institutions end up acting like... let's talk about... it depends on the laws in Brazil. [...]. In the case of helicoverpa, it was a matter of... for example, the action of a product. This product is prohibited only in Brazil, right? (Engineer responsible for crops).

While the interest of businesspeople was to eradicate the infestation quickly with the use of new products developed by agrochemical industries, ANVISA's objective was to prevent the use of these products as a precaution to the harmful effects that they could have on collective health. The actions of business cotton farmers in adopting solutions result from normative instruments with coercive force from government organizations, instead of a cognitive affinity with these organizations to deal with problems in the field. ANVISA is seen as an organization that creates barriers to solving common problems among business cotton producers, resulting in little affinity between these two entities. The social dimension is also promoted in the Responsible Brazilian Cotton (ABR) program, which was created in 2012 by ABRAPA and is aligned with the Better Cotton Initiative $(\mathrm{BCl})$ at an international level to encourage cotton farming guided by principles of sustainable development (Daviron \& Vagneron, 2011).

The accessed documents show that the studied conventional cotton company is certified by $A B R$, which checks criteria that include employment contracts, unsuitable conditions, and occupational health, observing the compliance with legal frameworks. Thus, ABR addresses 
the vulnerability of employees, mediating relations between farmers and government agencies such as the former Ministry of Labor and Employment (MTE) and the current Special Secretariat for Social Security and Labor (SEPRT).

Criticisms on the potential damage to agricultural business systems to the social wellbeing of rural communities serve as a stimulus for conventional cotton establishments to join the $\mathrm{BCl}$ and $\mathrm{ABR}$ programs. Thus, certification by these programs shows an affinity that is mediated between the managers of conventional cotton farming and the governmental bodies that inspect labor relations, guiding compliance with laws and regulations that protect the social cohesion of rural workers. However, the use of pesticides in crops is permitted by the standard defined in these programs, revealing a weakness in their proposals to be an instrument of sustainability in cotton farming. The collective health and life quality of rural workers have suffered losses due to chronic contact with pesticides in crops (Porto \& Soares, 2012), which created doubt concerning the criterion of $\mathrm{BCl}$ and $\mathrm{ABR}$.

In organic cotton farming, the social dimension is expressed in the gains in the infrastructure necessary for the life quality due to the relationship between farmers in the association studied and the managers of the PDHC. This relationship was established in the mid-2000s, even before the association formally existed when PDHC managers already provided support to farmers for their training. The president of the association said that "It was the best project that we have ever had here. When the Dom Helder Project arrived here, we did not have... we lacked energy, we lacked water, we lacked... and all the structures that we built were all through [the Project's] resource". Cohesive social ties facilitate the perception of the reputation built on past collaborative successes, which are a basis for trust and serve as a model for future collaborations (Putnam, 2002).

Over time, the examined relationship between the PDHC developed trust and formed a stock of social capital based on the reputation and the positive experiences that have been accumulated. Therefore, the accumulation of positive experiences becomes a dynamizing aspect of trust when it comes to establishing relationships between organic cotton associations and governmental organizations. A stock of social capital in the form of trust relationships was created between the members of the studied association and the managers of the PDHC, demonstrating the cumulative ownership of the social capital. These relationships of trust are built between managers of organizations based on positive collaborations in the past and make it possible to solve future problems of collective action through new collaborations.

In the association of organic cotton farming studied, the quality of agroecological production is a mechanism of improving the community's quality of life. This is the common interest among organizations that relate to this field. Furthermore, the promotion of collective actions and the democratization of decisions about the application of resources is promoted by the relations between government organizations and the association of farmers.

The trajectory of positive experience consolidated in the relationship of the association of organic cotton farming studied in this work with the PDHC, which promoted the quality of life with the distribution of access to electricity and piped water to 120 families, surpassed formal ties and intensified the cognitive affinity between its managers, as shown in the following statement made by the president of the association:

Even though the Dom Helder Project was not renewed this year, we had already created that cycle of trust with the people who oversaw managing. Then, when we have a problem, we look for them, we call them, I call them, we try to contact them. (President of APASPI).

A strong cognitive affinity in identifying problems and implementing solutions between the managers of the studied association and the PDHC is provided by the trusting relationship between them, representing the interrelationship between the relational and cognitive aspects of social capital (Tsai \& Ghoshal, 1998).

The presence of the PDHC in the community formed by members of the organic cotton association also promoted civic engagement in the transparency of the application of public 
resources, allowing farmers to monitor all investments that were carried out. According to the association's president, "[...] the resources that arrived here were properly managed because we had access to everything. So, we knew how every penny of the projects that arrived here at the settlement was spent." The association adopts participatory decision-making processes in identifying problems and implementing solutions, reinforcing transparency and civic engagement as elements of a democracy, which promotes the interconnection of the social and institutional dimensions of development (Spangenberg, 2002). The social dimension of development is also promoted in participatory certification systems, which represent gains in protection and social autonomy. The case of the studied association is similar to the performance of the Ecovida Network of Agroecology in southern Brazil. In these cases, the use of participatory certification as a mechanism for the recognition of organic production is an example with positive social impacts (Rover, 2011; Serva \& Andion, 2004).

\section{Environmental dimension}

Business cotton farming is raising interest in some issues related to sustainable development, especially regarding its relationship with the environment. ABRAPA indicated that the need to bring business cotton farming closer to the precepts of sustainability as a critical factor in the cotton production chain in the country, reinforcing the importance of the $\mathrm{BCl}$ and $\mathrm{ABR}$ programs (mentioned in the previous section). In addition to the benefits in the social dimension, these programs promote the environmental dimension of development by ensuring the proper destination of production residues, the preservation of watercourses and legal reserves, the recovery of degraded areas, the use of management practices, and compliance with environmental legislation.

It is important to mention that the documents accessed affirm the ABR certification of the studied conventional cotton farming company. The accusation of corporate farming systems as causing damage to the environment stimulates a response manifest by the implementation of sustainability programs. However, the criteria used by $\mathrm{BCl}$ and $\mathrm{ABR}$ do not mitigate known causes of environmental damage caused by business agriculture, such as the practice of extensive monoculture and the use of pesticides.

The $\mathrm{BCl}$ and $\mathrm{ABR}$ programs value compliance with environmental performance standards, including the Brazilian Forest Code and the Rural Environmental Registry System (SICAR), which mediates the trust relationships with governmental organizations linked to the Ministry of the Environment (MMA). These relations between conventional cotton farming companies, intermediated by $A B R$, with other governmental organizations that have jurisdiction over environmental issues are important to accompany the regulatory innovations that can be incorporated into $\mathrm{BCl}$ and $\mathrm{ABR}$. Thus, participation is facilitated by the elaboration of these normative innovations, which result from revision processes and comprise updates in the regulations with the incorporation of new issues. The result is a capability of compliance with laws enabling sustainable development (Ruggie \& Nelson, 2015). Therefore, the $\mathrm{BCl}$ and $\mathrm{ABR}$ programs can be revised to update their requirements for stricter environmental conduct, e.g. restricting the use of pesticides to the most advanced and least harmful technologies.

The identification of problems and the adoption of solutions by farmers in conventional cotton farming do not necessarily result from a cognitive affinity with the performance of government organizations, but from normative instruments with coercive force. The laws and regulations developed by governmental organizations are based on the identification of problems. These laws have the role of regulating the activities of farmers and force the adoption of prescribed solutions. According to the executive director of APIPA, "[...] everything is subject to legislation. Nothing is done outside the law. Therefore, today, all actions, the whole process goes through legislation, laws. Without laws, it is no use, you cannot do anything".

The harmful effects of the agrochemical industry on the environment have been discussed since the 1960s at the initiative of Rachel Carson. Despite this movement that led to prohibitions on some pesticides, the use of these products in large quantities is currently 
common among conventional cotton farmers as a solution to their production problems. In contrast to the recipes recommended by the multinationals, the farmers of conventional cotton farming, including the company studied, are seeking to develop their solutions internally through precision agriculture:

[...] (productivity gain) involves the development of more modern inputs and management techniques, such as the increased use of precision agriculture and the dense cotton system, more productive cultivars and better adapted to the edaphoclimatic conditions of the farming regions and greater efficiency in combating losses caused by attacks by pests and diseases. (Associação Brasileira dos Produtores de Algodão, 2013, p. 155).

Precision agriculture is an agronomic technique capable of reducing the use of pesticides due to the adaptation to the properties of the climate and soil. The positive economic performance that business cotton has achieved is partly due to the adequacy of productive activities to local soil and climate conditions. The case study of conventional cotton farming in southwest Piauí is an example of a group of entrepreneurs who are searching for regions with soil and climate conditions more suited to crops, stimulating the emergence of new agricultural frontiers.

In organic cotton farming, the association studied has purposes aligned with agroecology, promoting the environmental dimension of development broadly, as its social statute establishes among the organization's purposes: "[...] to carry out conservation, preservation, recovery, and sustainable management of the environment." This promotion of environmental assets includes organic quality and a consortium of crops, which prevent damage to soil and the reduction of biodiversity.

The organic quality of cotton grown by the studied association adds differentiation to its product, associated with the concept of being environmentally responsible. Once again, the relationships of trust with the PDHC and MAPA are highlighted because they provide the conditions and the recognition of organic cultivation. Besides that, this association cultivates crops in cooperation with cotton cultivation based on agroecological principles, such as corn, beans, sesame, pumpkin, and watermelon, as well as producing and processing honey and fruit. Thus, organic cotton farming promotes the environmental dimension, because it avoids the negative impacts of monoculture and the use of pesticides:

[...] we certify the cotton through that association. It is organic. The beans we obtain are organic. The corn we produce is organic, right? Every farmer with this kind of crop has an organic certificate. The association is great. Everything that we have in our farm is certified. The certification is valid for one year, but when the certification expires, we receive another one. (Member of the evaluation committee).

Depending on the context, the practice of organic agriculture respects agroecological science to a greater or lesser degree (Assis \& Romeiro, 2002, p. 73). The president of the studied association indicates that "[...] we are an agroecological farmer because we have a whole set of management techniques applicable to our area so that we do not degrade it, thus avoiding destroying our land. There has to be a land for it so that it becomes increasingly productive."

The relationship between this association and the technicians linked to the DHCP who guide agroecological practices results in access to non-redundant information, which becomes part of the opinions of the members of the association and is strengthened in a cognitive affinity between these actors. This issue is shown in the statement of an association manager below:

If there is a plague in the field, for example... that happened with us and we had this technician called Gean working for us here in cotton. Then, when we have a question about a pest, when we have a question about something that we do not know how to solve, then we call him and ask: "hey, what do I use?" Thus, these doubts are resolved. (Manager of APASPI). 
The search for positive effects on the environment is an intrinsic element of the ideal proposed by the agroecological agriculture movement, of which this association is part. Its relationship with the DHCP provides the construction and development of skills for farmers regarding the knowledge and practices of agroecology, resulting in cognitive affinity between these organizations. This affinity is strengthened with the observation of the associated impacts over time.

The access of association members to new sources of information, which are civil society organizations linked to the DHCP to provide training in agroecological knowledge, results in a learning process that promotes and constitutes a social capital of intermediation (Burt, 2007). Therefore, the PDHC assumes the role of intermediary, having facilitated access both to the practical knowledge of family farmers in the northeastern semiarid and to the appropriate knowledge by civil society organizations for training on agroecological science. Thus, the relationships of the association members with the managers of the PDHC and the technicians of civil society organizations constitute a structural configuration that enhances the quality of social capital, because they allow the flow of values, meanings, and diverse knowledge, without homogenization. This property also allows adaptations in agroecological science to be applied to the Caatinga biome.

Table 5: Analysis of the observed organizations

\begin{tabular}{|c|c|c|}
\hline & Conventional cotton farming & Organic cotton farming \\
\hline \multirow[t]{3}{*}{ Economic assets } & CONAB (High social capital) & INCRA (Low social capital) \\
\hline & MAPA (High social capital) & EMBRAPA (High social capital) \\
\hline & DNIT (High social capital) & MAPA (High social capital) \\
\hline \multirow[t]{2}{*}{ Social assets } & ANVISA (Low social capital) & MAPA (High social capital) \\
\hline & $\begin{array}{l}\text { MTE and SEPRT (Low social capital; } \\
\text { relationship intermediated by the ABR } \\
\text { program) }\end{array}$ & PDHC (High social capital) \\
\hline \multirow{2}{*}{$\begin{array}{l}\text { Environmental } \\
\text { assets }\end{array}$} & \multirow{2}{*}{$\begin{array}{l}\text { MMA (Low social capital; relationship } \\
\text { intermediated by the ABR program) }\end{array}$} & MAPA (High social capital) \\
\hline & & PDHC (High social capital) \\
\hline
\end{tabular}

Source: Prepared by the author.

Table 5 summarizes the comparison between the organizations observed, shows their relationships that constitute low or high social capital, and indicates the development assets promoted. The conclusions of the study are presented below.

\section{Conclusions}

In this study, the institutional dimension in conventional and organic cotton farming was compared, considering the relationships between farms and government organizations. Thus, the analysis allowed advancement in the understanding of how relationships with the government can increase the effectiveness of its policies for sustainable development. The analysis of governmental relationships with conventional production compared to the government's relationships with organic production systems contributed to an understanding of the institutional frameworks that involve rural organizations. Social purposes are promoted by the association of organic cotton farming through its relationship with the DHCP and the institutionalization of a democratic management system, including the implementation of participatory certification and the strengthening of social autonomy among its members. The studied association also has environmental purposes, which can be observed by its actions with the objectives of the conservation of local biodiversity, avoiding the use of substances and productive processes harmful to the environment. These results reinforce the premise that relations with governmental organizations in organic agriculture are oriented towards economic, social, and environmental purposes. 
In the case of the conventional cotton farming company, relationships with governmental organizations are intermediated by the ABR program for the exchanged content or shared values with social and environmental determinations. The results obtained in the analysis of the studied company support the proposition that, in conventional agriculture, relations with governmental organizations are predominantly oriented towards economic objectives. The relations that this company establishes with the government were identified at the limit of the method used, and there may be other relationships that were not analyzed, e.g. with the banking system that executes the credit policies. In turn, the case of family-based organic cotton farming comprises relationships oriented by economic, social, and environmental objectives.

In conventional cotton farming, the affinity with government organizations in identifying problems and adopting solutions results from the compliance with normative instruments. In this sense, normative innovations are required, which, according to Ruggie \& Nelson (2015), comprise updates to regulations through the incorporation of new issues, capable of making compliance with laws in conduct sufficiently oriented towards sustainable development. Thus, the legislation referring to agricultural establishments can be subject to revisions and updates to its requirements. The process guides business cotton farming towards more rigorous sustainability conduct, e.g. requiring the reduction of the use of pesticides.

This study contributes to the understanding that the decision to invest in the organic or conventional agriculture system leads to different institutional dynamics, strengthening of the interdependence relationships between different governmental organizations with the organizations comprised of farmers. The main theoretical contribution of the study is the highlight of the qualifying property of the transacted contents and the shared meanings in the relationships that constitute the social capital. In turn, the structural configuration of these relationships allows a greater diversity of values or reinforcing homogeneous meanings. Although social capital is a precondition for greater citizen participation, it can lead to harmful consequences when it is available to organizations with immoral purposes (Chambers \& Kopstein, 2001). The present study advances these discussions by analyzing the institutional dimension oriented towards sustainable or spurious development purposes, according to the discussions reported by Santos (2011) and Haddad (1999).

Although government financial institutions are known as important agents in financing private investments and public policies in several sectors, including agriculture, the results of this study did not present evidence that a more in-depth analysis of the relationships with these organizations is needed. It is suggested that future studies perform a comparative analysis of the relationships of productive business organizations and civil society with government banks. Moreover, the theory can advance from discussions on public governance, democratic management, and the co-production of public services, indicating important elements for understanding the institutional dimension of sustainable development.

\section{References}

Aguiar, G. A. M., Lima Filho, R. R., \& Torres-Junior, A. M. (2013). A última fronteira agrícola. AgroANALYSIS, 33(5), 15-16.

Altieri, M. A., \& Nicholls, C. I. (2012). Agroecology scaling up for food sovereignty and resiliency. Sustainable Agriculture Research, 11, 1-29.

Alves, L. R. A., Barros, G. S. A. D. C., \& Bacchi, M. R. P. (2008). Produção e exportação de algodão: Efeitos de choques de oferta e de demanda. Revista Brasileira de Economia, 62(4), 381-405.

Andrada, C. F., \& Sato, L. (2014). Trabalho e política no cotidiano da autogestão: a rede Justatrama. Psicologia \& Sociedade, 26(spe), 3-13.

Andrews, R. (2010). Organizational social capital, structure and performance. Human Relations, 63(5), 583-608.

Assis, R. L. D. (2006). Desenvolvimento rural sustentável no Brasil: perspectivas a partir da integração de ações públicas e privadas com base na agroecologia. Economia Aplicada, 10(1), 75-89. 
Assis, R. L., \& Romeiro, A. R. (2002). Agroecologia e Agricultura Orgânica: controvérsias e tendências. Desenvolvimento e Meio Ambiente, 6, 67-80.

Associação Brasileira dos Produtores de Algodão - ABRAPA. (2013). A cadeia do algodão brasileiro: safra 2012/2013 - desafios e estratégias. Brasília: ABRAPA.

Bardin, L. (2006). Análise de conteúdo. Lisboa: Edições 70.

Beltrão, N. E. M., Vale, L. S., Marques, L. F., Cardoso, G. D., Silva, F. V. F., \& Araújo, W. P. (2010). O cultivo do algodão orgânico no semi-árido brasileiro. Revista Verde de Agroecologia e Desenvolvimento Sustentável, 5(5), 8-13.

Bijl, R. (2011). Never waste a good crisis: towards social sustainable development. Social Indicators Research, 102(1), 157-168.

Brasil. Ministério da Agricultura, Pecuária e Abastecimento. Secretaria de Desenvolvimento Agropecuário e Cooperativismo. (2008). Produtos orgânicos: sistemas participativos de garantia. Brasília: Mapa/ACS. Retrieved in 2020, July 29, from https://www.gov.br/agricultura/ptbr/assuntos/sustentabilidade.

Brasil. Ministério da Agricultura, Pecuária e Abastecimento. (2012). Ata. Reunião ordinária n. 28 da Câmara Setorial da Cadeia Produtiva do Algodão e Derivados. Brasília: Mapa/Cgac.

Burt, R. S. (2007). Secondhand brokerage: Evidence on the importance of local structure for managers, bankers, and analysts. Academy of Management Journal, 50(1), 119-148.

Chambers, S., \& Kopstein, J. (2001). Bad civil society. Political theory, 29(6), 837-865.

Coleman, J. S. (1988). Social capital in the creation of human capital. American Journal of Sociology, 94, S95-S120.

Companhia Nacional de Abastecimento - CONAB. (2016). Algodão em caroço - Brasil (Série Histórica de Produtividade. Safras 1976/77 a 2015/16). Retrieved in 2016, May 3, from http://www.conab.gov.br/

Cruz, M. S., \& Maia, S. F. (2008). Desempenho da cotonicultura brasileira pós-abertura econômica. Revista Economica do Nordeste, 39(2), 263-284.

Daviron, B., \& Vagneron, I. (2011). From commoditisation to de-commoditisation... and back again: Discussing the role of sustainability standards for agricultural products. Development Policy Review, 29(1), 91-113.

DiMaggio, P. J., \& Powell, W. W. (1983). The iron cage revisited: Institutional isomorphism and collective rationality in organizational fields. American Sociological Review, 48(2), 147-160.

Espinosa, H. R., Gómez, C. J. R., \& Betancur, L. F. R. (2018). Factores Determinantes de la Sostenibilidad de las Agroempresas Asociativas Rurales. Revista de Economia e Sociologia Rural, 56(1), 107-122.

Faria, M. V. C. M., \& Pereira, J. A. (2012). A rede de economia solidária do algodão agroecológico: desenvolvimento humano, sustentabilidade e cooperação entre os produtores rurais do Estado do Ceará. Organizações Rurais \& Agroindustriais, 14(3), 395-408.

Ferreira Filho, J. B. D. S., Alves, L. R. A., \& Villar, P. M. D. (2009). Estudo da competitividade da produção de algodão entre Brasil e Estados Unidos-safra 2003/04. Revista de Economia e Sociologia Rural, 47(1), 59-88.

Ferro, A. B., \& Castro, E. R. D. (2013). Determinantes dos preços de terras no Brasil: uma análise de região de fronteira agrícola e áreas tradicionais. Revista de Economia e Sociologia Rural, 51(3), 591609.

Flores, P. (2013). Organic agriculture in Latin America and the Caribbean. In H. Willer, J. Lernoud, \& L. Kilcher (Eds.), The World of Organic Agriculture. Statistics and Emerging Trends 2013. Switzerland: FiBLIFOAM.

Food and Agriculture Organization of the United Nations. (2020). FAOSTAT statistical database. Rome: FAO. Retrieved in 2020, July 29, from http://www.fao.org/faostat/.

Haddad, P. R. (1999). A concepção de desenvolvimento regional. In P. R. Haddad (Org.). A competitividade do agronegócio e o desenvolvimento regional no Brasil: estudos de clusters (pp. 9-22). Brasília: CNPq/Embrapa.

Hartmann, A. S., \& Serafim, M. C. (2014). Uma proposta de modelo de análise do capital social organizacional. In: Anais do VIII Encontro de Estudos Organizacionais da ANPAD. São Paulo: ANPAD. 
Hodgson, G. M. (1998). The approach of institutional economics. Journal of Economic Literature, 36(1), 166-192.

Jalfim, F., Sidersky, P., Rufino, E., Santiago, F., \& Blackburn, R. (2013). Geração do conhecimento agroecológico a partir da interação entre atores: a experiência do Projeto Dom Helder Camara. Agriculturas, 10(3), 26-34.

Jorge, M. (2009). Desenvolvimento Produtivo para evitar a volta da vulnerabilidade externa. In J. P. R. Velloso, \& R. C. Albuquerque (Orgs.), Na crise Global, como ser o melhor dos BRICs. Rio de Janeiro: Elsevier.

Lopolito, A., Nardone, G., \& Sisto, R. (2011). Towards a comprehensive evaluation of local action groups in LEADER programmes. New Medit: Mediterranean Journal of Economics, Agriculture and Environment, $10(1), 43$.

March, J. G., \& Olsen, J. P. (2008). Neo-institucionalismo: fatores organizacionais na vida política. Revista de Sociologia e Politica, 16(31), 121-142.

Mattos, P. L. C. (2005). A entrevista não-estruturada como forma de conversação: razões e sugestões para sua análise. Revista de Administração Pública-RAP, 39(4), 823-846.

Melo, P. T. N. B. (2013). Indicadores da dimensão institucional do desenvolvimento sustentável e os objetivos da Rio+ 20. Desenvolvimento em Questão, 11(23), 74-117.

Meyer, J. W., \& Rowan, B. (1977). Institutionalized organizations: Formal structure as myth and ceremony. American Journal of Sociology, 83(2), 340-363.

Nahapiet, J., \& Ghoshal, S. (1998). Social capital, intellectual capital, and the organizational advantage. Academy of Management Review, 23(2), 242-266.

North, D. C. (1990). Institutions, institutional change and economic performance. Cambridge: Cambridge University.

Pfahl, S. (2005). Institutional sustainability. International Journal of Sustainable Development, 8(1-2), 80-96.

Pignati, W., Oliveira, N. P., \& Silva, A. M. C. D. (2014). Vigilância aos agrotóxicos: quantificação do uso e previsão de impactos na saúde-trabalho-ambiente para os municípios brasileiros. Ciencia \& Saude Coletiva, 19, 4669-4678.

Porto, M. F., \& Soares, W. L. (2012). Modelo de desenvolvimento, agrotóxicos e saúde: um panorama da realidade agrícola brasileira e propostas para uma agenda de pesquisa inovadora. Revista Brasileira de Saúde Ocupacional, 37(125), 17-31.

Putnam, R. D. (2002). Comunidade e democracia: a experiência da Itália moderna (2. ed.). Rio de Janeiro: FGV.

Ribeiro, F. J., \& Markwald, R. (2009). Balança Comercial e déficits em transações correntes: de volta à vulnerabilidade externa? In J. P. R. Velloso, \& R. C. Albuquerque (Orgs.). Na crise Global, como ser o melhor dos BRICs. Rio de Janeiro: Elsevier.

Rover, O. J. (2011). Agroecologia, mercado e inovação social: o caso da Rede Ecovida de Agroecologia. Ciências Sociais Unisinos, 47(1), 56-63.

Ruggie, J. G., \& Nelson, T. (2015). Human Rights and the OECD Guidelines for Multinational Enterprises: Normative Innovations and Implementations Challenges (Corporate Social Responsibility Initiative Working Paper, 66). Cambridge, MA: John F. Kennedy School of Government, Harvard University.

Sabourin, E. (2007). Que política pública para a agricultura familiar no segundo governo Lula? Sociedade e Estado, 22(3), 715-751.

Sampaio, G. C., Marini, M. J., \& Santos, G. D. (2018). Capital Social e Ações Conjuntas: um estudo de caso no Arranjo Produtivo de vinhos de altitude catarinense. Revista de Economia e Sociologia Rural, 56(4), 605-622.

Santos, G. R. (2011). Políticas públicas e expansão da agroenergia no Brasil: contradições e desafios à sustentabilidade no ambiente rural em regiões do Cerrado (Tese de doutorado). Centro de Desenvolvimento Sustentável, Universidade de Brasília, Brasília.

Serva, M., \& Andion, C. (2004). O Controle Coletivo dos Riscos Ambientais na Produção de Alimentos: uma análise do sistema de certificação participativa na Rede Ecovida de Agroecologia. In Anais do $2^{\circ}$ Encontro Nacional da Associação Nacional de Pós-Graduação e Pesquisa em Ambiente e Sociedade. São Paulo: ANPPAS. 
Silva, G. G., Vilpoux, O. F., Cheung, T. L., \& Defante, L. R. (2016). Agricultura familiar e cooperação: caso da COOP-GRANDE no município de Campo Grande (MS). Estudos Sociedade e Agricultura, 24(2), 444470.

Souza, R. T., \& Caldas, E de L. (2018). Redes alimentares alternativas e potencialidade ao desenvolvimento do capital social. Estudos Sociedade e Agricultura, 26(2), 426-446.

Spangenberg, J. H. (2002). Institutional sustainability indicators: an analysis of the institutions in Agenda 21 and a draft set of indicators for monitoring their effectivity. Sustainable Development, 10(2), $103-$ 115.

Tsai, W., \& Ghoshal, S. (1998). Social capital and value creation: The role of intrafirm networks. Academy of Management Journal, 41(4), 464-476.

United Nations. (1992). Resources: outcomes, \& frameworks. Agenda 21. Retrieved in 2013, March 11, from https://sustainabledevelopment.un.org/

Veblen, T. (1987). A teoria da classe ociosa: um estudo econômico das instituições. São Paulo: Nova Cultural.

Vogelpohl, T., \& Aggestam, F. (2012). Public policies as institutions for sustainability: potentials of the concept and findings from assessing sustainability in the European forest-based sector. European Journal of Forest Research, 131(1), 57-71.

Yin, R. K. (2005). Estudo de caso: planejamento e métodos (3. ed.). Porto Alegre: Bookman.

Data de submissão: 29 de maio de 2019.

Data de aceite: 18 de dezembro de 2020.

Sistema de Classificação do Journal of Economic Literature (JEL): R11 Regional Economic Activity: Growth

Development, Environmental Issues, and Changes 